\title{
ZIEMIA OJCÓW. POMORZE ZAODRZAŃSKIE W LITERATURZE KASZUBSKIEJ
}

\author{
DANIEL KALINOWSKI ${ }^{1}$ \\ (Akademia Pomorska w Słupsku)
}

\begin{abstract}
Słowa kluczowe: literatura kaszubska, tożsamość i multikulturalizm, związki międzykulturowe, motywy pomorskie w literaturze
\end{abstract}

Key words: Kashubian literature, identity and multiculturalism, intercultural relations, Pomeranian motifs in literature

\begin{abstract}
Abstrakt: Daniel Kalinowski, ZIEMIA OJCÓW. POMORZE ZAODRZAŃSKIE W LITERATRURZE KASZUBSKIEJ. „PORÓWNANIA” 12, 2013, T. XII, s. 193-207. ISSN 1733-165X. Artykuł związany jest z opisem Zaodrza (dzisiejsze Vorpommern) zapisanym w literaturze kaszubskojęzycznej. Literackie przedstawienie przestrzeni kulturowej Rugii czy Połabia ma za zadanie ukazać słowiańską i kaszubską moc istniejącą w Europie jeszcze przed dominacją chrześcijaństwa, ma również ideowo wspomóc walczące o swoje domowe i państwowe ojczyzny ludy słowiańskie. Zaodrze dla Kaszubów to jednocześnie chlubna i ciemna przeszłość słowiańszczyzny wciąż na nowo odciskająca się we współczesności. Utwory literatury kaszubskiej eksploatują treści historyczne, które są wywiedzione z zapisków dawnych kronikarzy, pełniąc rolę "dziejów bajecznych", które miały przede wszystkim funkcję terapeutyczną. Rozpamiętywanie bitwy pod Reknicą, losów Słowian połabskich, znaczenia Arkony miało na społeczność kaszubską działać dydaktycznie i otrzeźwiająco. Dydaktycznie - ponieważ dawało wiedzę o ziemi ojców, otrzeźwiająco - ponieważ zachęcało do świadomościowego przebudzenia. Akcentowanie prakaszubskości Zaodrza w sytuacji zagrożenia germanizacją stawiało aktualne niedogodności i zagrożenia w szerokiej historiozoficznej perspektywie, która przynosiła pewną nadzieję dla kaszubskiej samoświadomości kulturowej.
\end{abstract}

Abstract: Daniel Kalinowski, THE LAND OF THE ANCESTORS. WEST POMERANIA (VORPOMMERN/ZAODRZE) IN KASHUBIAN LITERATURE. “PORÓWNANIA" 12, 2013, Vol. XII, p. 193-207. ISSN 1733-165X. The article is related to the description of Zaodrze (today known as Vorpommern) which is stored in the Kashubian literature. The literary representation of cultural

${ }^{1}$ Correspondence Address: dankalin@poczta.onet.pl 
space of Rugia and Połabia is to show Slavic and Kashubian power existing in Europe yet before the domination of Christianity. It also provides ideological support for Slavic nations, fighting for their home and state homelands. For the Kashubians Zaodrze is both the glorious and dark past of Slavs repeatedly imprinting itself in the present. Works of Kashubian literature exploit historical contents derived from the writings of ancient chroniclers, being "the fabulous history" that had primarily a therapeutic function. Remembrance of the Battle of Reknica, the fate of the Polabian Slavs and the meaning of Arkona were to exert a didactic and sobering influence on the Kashubian community. Didactic - because it gave the knowledge of the land of their fathers, sobering - as it encouraged the awakening of consciousness. Emphasizing that Zaodrze had been originally Kashubian in the situation of the Germanisation threat, placed the current drawbacks and risks in a wide historiosophical perspective, which brought some hope for Kashubian cultural self-awareness.

\section{MITY FUNDACYJNE FLORIANA CEYNOWY}

Literatura kaszubska to piśmiennictwo tworzone we własnym języku od połowy XIX wieku². Za sprawą pism Floriana Ceynowy zaistniała wówczas kaszubska etnografia, publicystyka społeczna, polityczna i historyczna, teksty religijne, dialogi literackie oraz prace językoznawcze ${ }^{3}$. Wśród tak wielu tekstów stanowiących podstawę całej późniejszej tradycji kaszubskojęzycznej, Ceynowa poruszył również problematykę historii Kaszub i Kaszubów, wyprowadzając z dostępnych mu opracowań znamienne przekonania historyczno-ideowe, których podstawowym celem było uświadomienie ważnej roli kultury kaszubskiej, jaką odegrała na słowiańskiej - i szerzej europejskiej - arenie dziejowej. Skrótowo tutaj referując ten profil zainteresowań Ceynowy, należy zauważyć, iż wywodził on Kaszubów z plemion słowiańskich, które żyły na Pomorzu (zarówno tym, które dziś należy

${ }^{2}$ Za literaturę kaszubską uważam nade wszystko piśmiennictwo powstałe w języku kaszubskim. Nie przywołuję tutaj twórczości kaszubsko-pomorskiej, która tworzona po polsku przez Kaszubów lub po polsku przez nie-Kaszubów dotyczy tej samej przestrzeni geograficznej, społecznej czy obyczajowej, co kaszubska, lecz z inaczej postawionymi akcentami odnośnie kwestii etnicznych. Wybór pierwszej definicji zapewnia klarowność wypowiedzi i uwypukla myślenie samych Kaszubów. O problematyce terminologicznej patrz w tekstach: L. Bądkowski, O wspótczesnej literaturze kaszubsko-pomorskiej, w: Pomorze Gdańskie. T. IV: Literatura i jezzyk. Red. S. Gierszewski. Gdańsk 1967, s. 47-73; J. Samp, Literatura kaszubska, w: Pomorze - mała ojczyzna Kaszubów (Historia i wspótczesność) / Kaschubisch - Pommersche Heimat (Geschichte und Gegenwart). Red. J. Borzyszkowski, D. Albrecht. Gdańsk-Lubeka 2000, s. 653; A. Kuik-Kalinowska, Tatczëzna. Literackie obrazy przestrzeni Kaszub. Słupsk-Gdańsk 2011, s. $17-22$.

${ }^{3} \mathrm{O}$ Ceynowie w większych opracowaniach: J. Karnowski, Dr Florian Ceynowa. Oprac. i posł. J. Treder. Gdańsk 1997; I. Pieróg, Florian Stanisław Ceynowa. Życie i działalność. Toruń 2009; A. Kuik-Kalinowska, D. Kalinowski, Od Smętka do Stolema. Wokót literatury Kaszub. Gdańsk-Słupsk 2009, s. $67-110$. 
do Polski, jak i tym, które należy do Niemiec). W swoim tekście historycznym pisze on:

Zemja Kaszebsko cignęła sę ju v nodavniejszech czasach wód mórza Baltickjeko, czele, jak me je teros zovjeme, Vjelgjeko, jasz pó rzeki Notecę e Vartę miedze Wódrą e Visłą. Ledovji tutejszemu dovale dzejopjisorze rożne nazwjistka: Venetóv czele Vendov, Słovjanów, Pomórzanov, Kaszebów ${ }^{4}$.

Terytorialnie Kaszubi, według Ceynowy, zajmowali tereny między ujściem Wisły i Odrą, od brzegów Bałtyku do linii wyznaczanej przez bieg rzek Warty i Noteci. Ze względu jednak na więzy krwi ze Słowianami połabskimi, także i terytorium leżące po zachodniej stronie Odry kaszubski publicysta uważał je za swojskie i poniekąd rodzime.

Drugie przekonanie Ceynowy akcentowało pradawny konflikt słowiańskogermański, w którym idealizowani Słowianie-Kaszubi cofali się przed naporem Niemców. Waleczność honorowych i pokojowo nastawionych do świata Kaszubów przegrywały tutaj z bezwzględnością i podstępem ze strony germańskiej5. Trzecia wywoływana przez pomorskiego badacza kwestia związana była $\mathrm{z}$ aktualizowaniem dawnego konfliktu wspólnot plemiennych $\mathrm{z}$ aktualną $\mathrm{w}$ dziewiętnastym wieku walką narodową między państwem pruskim a etnosami słowiańskimi wchodzącymi w jego skład.

Uwagi Ceynowy dotyczące najdawniejszej przeszłości Kaszubów i uwspółcześniania ich w nowych okolicznościach kulturowych zostały przez kolejne pokolenia twórców kaszubskich dobrze zapamiętane. Wielokrotnie wracały one w literaturze najpierw w sporadycznych nawiązaniach, później szerzej potraktowanych motywach lub wreszcie $w$ budowanych mitach tożsamościowych. Oczywiście nie znaczy to, że każdy z późniejszych autorów literatury kaszubskiej w swoich zainteresowaniach dotyczących Zaodrza sięgał wyłącznie do prac Ceynowy. Myślenie o prehistorii Kaszubszczyzny rozgrywającej się na Zaodrzu stało się z czasem, a zwłaszcza w latach trzydziestych $X X$ wieku, jednym z elementów poszukiwania rudymentów własnej kulturowej odmienności, w którym dorobek Ceynowy i innych historyków inspirował do dyskursu tożsamościowego.

\section{ZAODRZE W NOSTALGICZNEJ AURZE}

Pojawiające się na przełomie XIX i XX wieku nowe pokolenie działaczy kaszubskich zwane Młodokaszubami podjęło wysiłek, aby zachować swą tożsamość

\footnotetext{
${ }^{4}$ F. Ceynowa, Kile stov wo Kaszebach e jich zemi przez Wójkasena. Kraków 1850, s. 5-6.

${ }^{5}$ F. Ceynowa, Die germanisierung der Kaschuben. Von einem Kaschube. „Jahrbücher für Slawische Literatur, Kunst und Wissenschaft" [red. J. P. Jordan] 1843, z. 4.
} 
kulturową $\mathrm{w}$ oparciu o wspólnotę z tradycją polską. W sensie przynależności rodowej i terytorialnej uważali się za Kaszubów, lecz jednocześnie na wyższym, narodowym planie za Polaków. Ich hasło „co kaszubskie - to polskie” było gestem sprzeciwu wobec germanizacji i sygnałem podkreślającym identyczność zabiegów o zachowanie polskości w zaborze pruskim z działaniami konserwującymi kaszubskość. Nie byli bezkrytyczni wobec polskości, zwłaszcza w realiach administracyjnych i politycznych odrodzonej na Pomorzu w 1920 roku Rzeczpospolitej, lecz mimo to postulowali swoistą kulturową federacyjność Kaszub i Polski' ${ }^{6}$.

W swym artystycznym i ideowym nawiązywaniu do Zaodrza Młodokaszubi wybierali dwa dukty: artystyczny oraz popularnonaukowy. W pierwszym powstały liryki i powieść Aleksandra Majkowskiego, dramat Jana Karnowskiego oraz poemat Leona Heykego. W drugim rozprawa historyczna Majkowskiego.

Rozpocznijmy od obrazka scenicznego Jana Karnowskiego Ötrôk Swiãtowida, w którym jedną z ważniejszych ideowo postaci dramatu o szczególnie mitotwórczej funkcji jest figura fantastyczna - Gryf7. W monologu wygłaszanym przez dawne bóstwo słowiańskie Swantewita słyszymy słowa:
Czas ju bùdzëc Grifa,
zaklãtégò na daleczi wëspie. -
tam òn spi ju dłudżénôsté wieczi.
Czedë płomiéń bùchnął na Arkónie,
ùniosłë gò wiôldżé wiatrë
na zaklãtą wëspã.
Dzysô jidze zorzô òbùdzeniô,
czas je bùdzëc Grifa,
żebë zatrzepòtôł skrzidłã swòjim
nad pòmòrsczim krajã,
wezwôł wòjska spiącé w Bòrzestowie
zaprowadzył lud nasz do gòntinë8.

W wypowiedzi tej pojawiły się elementy tak historyczne, jak i mitologiczne. Istnieją tutaj obok siebie na równych prawach: dawny historyczny upadek Arkony

${ }^{6}$ Najważniejsze opracowania dotyczące tej grupy działaczy kaszubskich to: C. Obracht-Prondzyński, J. Karnowski, Jan Karnowski (1886-1939). Pisarz, polityk i kaszubsko-pomorski działacz regionalny. Gdańsk 1999; J. Borzyszkowski, Aleksander Majkowski (1876-1938). Biografia historyczna. Gdańsk-Wejherowo 2002; J. Schodzińska, Franciszek Sędzicki (1882-1957). Działacz narodowy, regionalista i poeta kaszubski. Gdańsk-Wejherowo 2003.

${ }^{7}$ Szerzej o dramaturgii Karnowskiego pisałem w tekście: D. Kalinowski, Obraz - idea - tożsamość. O dramaturgii Jana Karnowskiego, w: J. Karnowski, Dramaty. Oprac. i przyp. M. Cybulski, wstęp C. Obracht-Prondzyński, D. Kalinowski, M. Cybulski. Biblioteka Pisarzy Kaszubskich. T. 6. Gdańsk 2011, s. 71-139.

8 J. Karnowski, Òtrôk Swiãtowida, w: tegoż, Dramaty, s. 379. 
jako ośrodka słowiańszczyzny przedchrześcijańskiej ${ }^{9}$ i jednocześnie ahistoryczne ludowe podanie o śpiącym wojsku w Borzestowie ${ }^{10}$. Faktografia miesza się zatem z fantazją, weryfikowalna rzeczywistość z fikcją. Gryf wypędzony ze swojej siedziby w Arkonie ma w wizji artystycznej powrócić i zaprowadzić nowy porządek. Fantastyczne zwierzę staje się w obrazach scenicznych Karnowskiego efektem specyficznej syntezy, nabiera cech emblematu, który jednoczy przeszłość polityczną Pomorzan ze współczesnością Kaszubów. Jako godło swym znaczeniem nawiązuje do waleczności, dumy i wytrwałości, jako zaś symbol wolności, bogactwa i spełnienia jest $\mathrm{w}$ dramacie przeciwstawiony Smętkowi - figurze zniewolenia, ubóstwa i niespełnienia ${ }^{11}$. Pesymistyczne zakończenie dramatu nie ma ostatecznego wydźwięku, ocalenie się jeszcze nie dokonało, przecież istnieje mityczna opowieść, która organizuje życie emocjonalne Kaszubów i daje nadzieję na przyszłość.

W podobnym znaczeniu mityzowanej wielkości Zaodrza pojawiają się w twórczości Aleksandra Majkowskiego wyspa Rugia z dwoma szczególnymi miejscami: Arkoną oraz Stopnym Kamem (niem. Stubbenkammer). Pierwsze z nich przywołane zostało głównie ze względu na aurę duchowości przedchrześcijańskiej, z powodu ponadlokalnego ośrodka kultu Światowida zniszczonego dopiero w drugiej połowie dwunastego wieku. Drugie miejsce pojawia się ze względu na imponujący znak natury, ów akt potęgi sił przyrody, której nieujarzmienie i surowość dobrze obrazowała naturę żyjących tutaj ludzi12. Obecność tych dwóch miejsc sprowadzona została do funkcji przypominania o kaszubskości Wielkiego Pomorza oraz do egzemplifikacji odrębnego od chrześcijańskiego i germańskiego świata duchowego dawnych Kaszubów ${ }^{13}$. Z kolei w najbardziej znaczącym utworze epickim Kaszub Życiu i przygodach Remusa Aleksandra Majkowskiego Zaodrze jest niczym krynica jednostkowego oraz zbiorowego odrodzenia. Przywołana w powieści przez szlachcica o pradawnym rodowodzie - pana Zabłockiego - ma wyjaśnić młodemu Remusowi historyczne dzieje kaszubszczyzny na Pomorzu:

${ }^{9}$ Arkona jako geograficzno-symboliczna przestrzeń Pomorza odmienne wykładnie w tradycji polskiej, kaszubskiej i niemieckiej. W ramach niniejszego artykułu przywołuję jedynie perspektywę kaszubską. Szerzej o problematyce piszę: D. Kalinowski, Arkona - od literackiego mitu ku antropologii kulturowej, w: Wielkie Pomorze. Mit i literatura. Red. A. Kuik-Kalinowska. Słupsk 2009, s. 109-135.

$10 \mathrm{O}$ sile owego podania może zaświadczać dramaturgia ks. Bernarda Sychty i jego Spiacé uejskue. Dramat kaszubski w czterech odstonach; Budzta spiacëch. Betlejem kaszubskie w 3 aktach oraz Przebudzenie. Dramat kaszubski. Jest to zresztą motyw wyraźnie istniejący także w Życiu i przygodach Remusa Majkowskiego.

${ }^{11}$ Figura gryfa znana jest $\mathrm{w}$ tradycji ludowej w różnych ujęciach; np.: Bojka o trzech mocarzach i ptochu Gryfie, w: Bajarz kaszubski. Bajki z "Gryfa" (1908-1912). Przyg. i wstęp J. Borzyszkowski. Wejherowo-Gdańsk 2005, s. 81-87.

12 Plastyczne przedstawienia tego miejsca na Rugii warte są oddzielnej interpretacji czynionej wedle optyki historii sztuki. Patrz choćby: R. Piechocki, Kap Arkona. Putbus 1997.

${ }^{13}$ Rozważa tę kwestię T. Linkner, Z literackiej mitologii i demonologii Kaszubów, w: Życie dawnych Pomorzan, [II]. Red. W. Łysiak. Bytów-Słupsk 2003, s. 93-110. 
Tam, cudze Vjisła bjeżi v morzé, mosz Gduńsk, tam chce Wodra, mosz Szczeceno. Zdrzë, jak linjijô morzo podbjegô tępym klinem do wuscô Wodrë i boczë, że przeszedłszë rzekę tę na levi brzeg, vjedno jesz stojisz na dovni zemji kaszubskji. Bo wona sę cignje po gorach bołteckjich jaż bezmała tęde, chdze stoji Berlin, stoleca Njemcóv, i miasto Roztoka, njedalek morzô ${ }^{14}$.

Zaodrze pojawia się również w innym miejscu powieści Majkowskiego, w jeszcze bardziej wzniosłej atmosferze. Myślę o profetycznie znaczącej wizji wypowiadanej przez Sławinę - ostatnią Kaszubkę, żyjącą w otoczeniu osiadłych na słowińskim Pomorzu Niemców. Przez użycie mowy wiązanej, opowieść o prehistorycznych Kaszubach staje się znakiem wciąż żywego mitu rodzimej ziemi, która w ujęciu autora Życia $i$ przygód Remusa jest jeszcze rozleglejsza terytorialnie, aniżeli to widział Florian Ceynowa. Tym razem z Zaodrza sięga się w liryku myślą ku Rugii, co ma być swoiście przeżywaną historią zachodnich Słowian, ich chwały i znaczenia, które pośrednio wypracowali także Kaszubi. W wierszu Majkowskiego czytamy:

Ga Łeba mdze na Sorbsko szła

A z Chołmu pjesnjô zgodë gra

$\mathrm{Ku}$ vschodu tu, na zochod tam,

Po bjołi Hel, po Stopni Kam,

Ga będze v gardła dvoje rzek

Wokręt z chorągvją Grifa bjegł,

A jimu pozdrovjenjé słoł

Wognjistim wokjem Revekol,

Ga wotrokji Veletóv mdą

Strzec wognji, chterne z grobóv żglą,

A te jak duna rozdmną sę

V płom wod Mutłavë jaż po Vkrę, -

Tej sprovdzi sę kaszubskji mit,

Tej vznjese ksążę Grifa szczit.

A przësągelë $v$ jego znam

Mdą z Helë jaż po Stopni Kam¹5.

W zacytowanym liryku pojawiają się nazwy geograficzne, które zakreślają obszar kulturowej obecności Kaszubów na całym tzw. Wielkim Pomorzu, a więc tym nazywanym jako Wschodnie (gdańskie), Zachodnie (szczecińskie) oraz Przednie (niemieckie -Vorpommern). Majkowskiemu nie idzie jednak o geografię rzeczywi-

${ }^{14}$ A. Majkowski, Żëcé i przigodë Remusa. Zvjercadło kaszubski. Oprac. i przypisy J. Treder, wstęp J. Borzyszkowski, A. Kuik-Kalinowska, J. Treder. Biblioteka Pisarzy Kaszubskich. T. 5. Gdańsk 2010, s. 369.

${ }^{15}$ A. Majkowski, Ga Łeba..., w: A. Majkowski, Żëcé i przigodë Remusa, s. 625-626. 
stą, lecz o przestrzeń mityczną. W przywołanym liryku Stopni Kam na Rugii staje się jeszcze jednym znakiem kaszubskości na równi z innymi pomorskimi miejscowościami, rzekami czy górą Rowokół. Pradawność pochodzenia etnicznego Kaszubów unaoczniona zostaje jeszcze poprzez nazwanie ich synami wcześniejszych mieszkańców pomorskich ziem - Wieletów ${ }^{16}$, co wzmacnia poczucie dumy i przekonanie o ciągłości cywilizacyjnej.

W jeszcze innej stylistyce, aniżeli Karnowski i Majkowski, nawiązał do Zaodrza Leon Heyke w poemacie Dobrogòst i Miłostawa (1939). To historyczny epos sławiący księcia Pomorza Świętopełka II, w którym rozgrywa się również idealistycznie przedstawiona miłość pomiędzy tytułowymi bohaterami. Ponieważ utwór dotyczy wydarzeń z trzynastego wieku, wciąż wśród występujących postaci pamięta się o dawnej potędze Słowian połabskich, za spadkobierców których uważają się Kaszubi. Heyke przywołuje Arkonę czy Retrę, aby ukazać dawne ośrodki życia duchowego Słowian (a wśród nich i Kaszubów) spełniające funkcje integracyjne. Wspominani są również dawni dowódcy związku wieleckiego czy książęta obodrzyccy jako szlachetni, dbający o tożsamość słowiańską władcy. Obydwa czynniki przedchrześcijańskiej kultury Słowian połabskich zostały tutaj swoiście zinterpretowane jako przykłady porządków politycznych i społecznych, którym hołdowali pradawni Kaszubi:

Ale dzyrsczi lud pòłabsczi zgromił wroga pòd Prisławą,

Òd ti chwili na sztërk dłudżi mir sã rozsodł na Pòmòrsczi.

Dzéń to béł tak wiéldzi chwałë, że na kòżdim ùroczëskù

Spiéw i tuńce i òfiarë całé dnie sã òdbiwałë.

Swaróg panowôł nad swiatã, Swiãtowit i Swiãtosława,

Redość szła òd gór do mòrza i òd Łabe jaż do Òdrë.

Dzéń ten chwałë rzucôł blasczi, het, jaż do daleczi Wisłë,

Trój sã redôł, trój sã zbiérôł i so cëda òpòwiôdôł ${ }^{17}$.

W poemacie Heykego coraz silniejsze wpływy chrześcijaństwa oraz ekspansja germańska zniszczyła kulturę słowiańską. Dawna wspólnota Słowian ugięła się pod tym naciskiem i wewnętrznie skonfliktowała, co doprowadziło do jeszcze większego kryzysu, a w efekcie do rozbicia dawnej jedności. Plemiona słowiańskie, przyjmując chrześcijaństwo i kulturę niemiecką, zatraciły swą odrębność kulturową. Jedynie Kaszubi, wedle poematu Heykego, mają jeszcze szansę ocalić swą

${ }^{16} \mathrm{Z}$ językoznawczego punktu widzenia lechicka grupa językowa była zróżnicowana. Jak pisze Jerzy Treder o zasięgu terytorialnym grup plemiennych: „a) Połabianie zajmowali biegun zachodni; b) Polanie wschodni i <lądowy>; c) Kaszubi zaś żyli nad Bałtykiem i pośrodku, choć silniej związani z Wieletami i Połabianami." (tenże, Historia kaszubszczyzny literackiej. Studia. Gdańsk 2005, s. 10).

17 L. Heyke, Dobrogòst i Miłostawa. Kaszëbsczé spiewë dzejowé w trzech brawa dach. Gdańsk 1999, s. 200 . 
samoświadomość, jeśli tylko nie zapomną o swojej heroicznej przeszłości. Powracanie do Zaodrza jest zatem w utworze aktem tożsamościowej samoobrony, napawaniem się świetnymi czynami przodków i czerpaniem odwagi do rozwiązywania współczesnych problemów.

Drugi dukt zainteresowań Młodokaszubów Zaodrzem widać w odmiennej optyce i stylu narracji w eseistycznej książce historycznej Historia Kaszubów Aleksandra Majkowskiego. Kaszubski artysta sięgnął do prapoczątków Kaszubów, aby zamanifestować nie tyle własne subiektywne spojrzenie na niemiecką i polską historiografię dotyczącą Pomorza, ile dążenie do wykreowania historycznego myślenia mitycznego ${ }^{18}$. Już pierwsze zdanie jego książki budziło sprzeciw u profesjonalnych historyków, lecz przeciętnym Kaszubom dawało poczucie dumy: „Kaszubi czyli Pomorzanie, najdawniej zwani Weletami są jedną z licznych gałęzi szczepu słowiańskiego, który zamieszkiwał Europę już w czasach przedchrystusowych ${ }^{19}{ }_{\text {". }}$. Tego typu, jak zacytowane, postrzeganie rzeczywistości historycznej, niekoniecznie w kategoriach faktów i zdarzeń, a mitu i projekcji kulturowej służyło docenieniu kaszubskich kwestii tożsamościowych. Majkowski jako lider ruchu Młodokaszubów uznawał swoich pobratymców za ostatnich potomków niezgermanizowanych plemion pomorskich, zaś za jedną z najważniejszych cech umożliwiających zachowanie tożsamości uważał związek z ziemią rodzinną. „Rodnô zemia", czyli ziemia-matka lub ziemia przodków, to w myśl artysty jednocześnie ziemia Wieletów i ziemia kaszubska. Majkowski, działając w warunkach pruskiego zaboru, walczył więc u uznanie tak kaszubskości, jak i słowiańskości Pomorza, co w szerszej perspektywie mogło się przysłużyć samoświadomości innych Słowian w państwie pruskim (np. Łużyczan) ${ }^{20}$. Warto tutaj jednak zauważyć, że Majkowskiego przywoływanie Zaodrza miało posmak nostalgicznego wspomnienia, utrata wpływów na zachód od Odry była już nieodwołalna. Rozpamiętywanie zmityzowanych dziejów Kaszubów miało zachęcić czytelników jego utworów do odważniejszego myślenia o sobie jako grupie o starożytnym etnosie. Gerard La-

18 Jerzy Samp zauważa tendencję do zwrócenia się w stronę tradycji historycznej i budowania wizji historiozoficznej opartą nie na materiałach dokumentalnych, "co będącej raczej projekcją kaszubszczyzny wymarzonej, [...] nawet za cenę mitologizacji faktów historycznych" (tenże, Poezja rodnej mowy, Gdańsk 1985, s. 39). Wagę tradycji historycznej w biografii i twórczości A. Majkowskiego wielokrotnie podkreśla także Józef Borzyszkowski we wspomnianej wcześniej monografii Aleksander Majkowski (1876-1938), op. cit.

${ }^{19}$ A. Majkowski, Historia Kaszubów. Gdynia 1938, drugie wydanie, z którego cytuję: Gdańsk 1991, s. 1.

${ }^{20}$ E. Siatkowska, Z badań nad problematyka tużycką i kaszubska, w: Badania kaszuboznawcze w XX wieku. Red. J. Borzyszkowski, C. Obracht-Prondzyński. Gdańsk 2001, s. 230. Szczególnie ciekawa jest propozycja badawcza Autorki, która polega na zestawianiu dyskursu historycznego, kulturowego i językoznawczego tradycji kaszubskiej i łużyckiej: „Badania kaszubsko-łużyckie pozwalają mieć wgląd w zamierzchłą przeszłość tego wymarłego etnikum, a także obserwować tendencje rozwojowe współczesnego słowiańskiego społeczeństwa pomorsko-połabskiego". 
buda uważał zainteresowania Młodokaszubów historią za ich programowy akt ideowo-polityczny:

Gdy rozglądamy się w dziejach budzenia się w XIX wieku świadomości narodowej Kaszubów - zarówno w jej słowianofilskiej jak i polonofilskiej odmianie - mocno uwydatnia się fakt, jak wielką rolę dla jej odrodzenia wyznaczano historii. [...] Głosząc więc hasła o konieczności trwania przy wierze i obyczaju ojców, samoobrony własnego stanu posiadania, zespalania własnych sił celem sprostania zagrożeniom wywłaszczeniowym ze strony zaborcy, ukazując mizerię dnia dzisiejszego i perspektywę jaśniejszej przyszłości - stale odwoływali się do blasków i osiągnięć przeszłości, wprawdzie w czasie tak bardzo odległej, ale przecież dającej się przybliżyć i przeżyć od nowa duchem. Ponieważ sami dokładnie jej nie znali, tym łatwiej było im przekształcać przekaz tradycji w mit i opowieść 21 .

\section{TRAGEDIA ZAODRZA, KTÓRA OCALA}

Do przesłań Aleksandra Majkowskiego, Jana Karnowskiego i Leona Heykego, dotyczących zaodrzańskiego Pomorza, dołączyli zrzeszeńcy, kolejne pokolenie działaczy kaszubskich działających od lat trzydziestych XX wieku ${ }^{22}$. Uważali się za kontynuatorów programu odrodzenia tożsamościowego Młodokaszubów, choć zdecydowanie mocniej podkreślali kwestię odrębności kulturowej Kaszubów wobec Polaków. Wśród zrzeszeńców Jan Trepczyk, Aleksander Labuda i Jan Rompski nawiązywali w swej twórczości do heroicznych dziejów Słowian i Kaszubów na Zaodrzu, czyniąc z tego wyrazisty element przesłania ideologicznego ${ }^{23}$. Podejmowali, co prawda, myśl Majkowskiego, lecz wyolbrzymiali ją w stałą tendencję tematyczną, w aktywistyczne hasła, pełne emocjonalnego zaangażowania. Już nie wystarczała im nuta nostalgicznego smutku jak u Młodokaszubów, lecz tworzyli liryki-wezwania, wiersze-pieśni i dramaty-przesłania, w których zaodrzańskie Pomorze wyrastało na utracone dziedziny ojców, które dla zachowania swojej inności kulturowej należy stale przywoływać i stale się nimi inspirować, aby nie popełniać podobnych błędów w nowych realiach historycznych.

${ }^{21}$ G. Labuda, O Aleksandra Majkowskiego „Historii Kaszubów”, w: Zapiski kaszubskie, pomorskie i morskie. Wybór pism. Gdańsk 2000, s. 351.

22 Krótką charakterystykę literatury i specyfiki działalności zrzeszeńców opisuje A. Bukowski, Regionalizm kaszubski. Ruch naukowy, literacki i kulturalny. Zarys monografii historycznej. Poznań 1950, s. 291-298 oraz F. Neureiter, Historia literatury kaszubskiej. Próba zarysu. Przeł. M. Boduszyńska-Borowikowa. Gdańsk 1982, s. 168-204.

${ }^{23}$ Jak czytamy w jednej z publicystycznych wypowiedzi Trepczyka: „Każdy atak Niemiec, skierowany przeciwko nam, odpierać będziemy przeciwatakiem, domagając się ziem nam zabranych; mamy bowiem odwieczne prawo historyczne tak do Gdańska, stolicy Pomorza wschodniego, do Oliwy, gdzie spoczywają nasi książęta, jak i do całego Pomorza Zachodniego - aż daleko poza Odrę". Cyt. za: A. Bukowski, op. cit., s. 293. 
Zacznijmy od Jana Trepczyka i jego Piesniô Wenedów, w której odnajdziemy bezpośrednie nawiązanie do tyleż rzeczywistych, co i mitycznych ziomków - Wenedów i Pomorzan ${ }^{24}$. Trepczyk bez wahania utożsamia Kaszubów z Pomorzanami i Wenedami, a więc z wszystkimi Słowianami znad południowego brzegu Bałtyku, co w specyficzny sposób, za pomocą środków artystycznych, zwiększa poczucie liczebności, zasięg terytorialny i kulturotwórczą zasługę żywiołu kaszubskiego na Pomorzu. Ziemia rodzinna to opiewana przez poetę wartość najwyższa, której utrata jest równoznaczna $z$ utratą bytu. Stąd najwyższy stan emocjonalnego uniesienia, wyrazy miłości, szacunku i oddania w pieśniach, które przybierają w tym i innych lirykach formę hymniczną.

W innym liryku Jana Trepczyka Marsz Naszińców motyw słowiańskich plemion zaodrzańskich został użyty $\mathrm{w}$ funkcji integracyjnej ${ }^{25}$. Na planie wyrażanych treści światopoglądowych i w swoistym natchnieniu podmiot z Marsza Naszińców nie tyle wyraża swoje poglądy, co wypowiada zdanie kaszubskiej zbiorowości. Wersy utworu pełne wykrzyknień i zawołań podnoszą żywotność dawnych tradycji Słowian. Czytamy tutaj:

Leno jurno, wespół wiérno

Stójma kole stanicë

Czôrno-żôłtyj, Wendów sztôłtu,

Co sę mionem Gryfa zwie!26

Radosny okrzyk: „Héj, ma młodi - z Wendów rodu” w rytmicznym układzie wierszowym zachęca do działania, do zamanifestowania swojej tożsamości w opozycji do Niemców czy nawet swoistej niechęci do Polaków. Właśnie postawienie Kaszubów nie tyle wraz, ale obok Polaków, było najbardziej wyrazistą cechą odróżniającą zrzeszeńców od wcześniejszych Młodokaszubów27. Trepczyk sięgając do symboliki i mitów Kaszubów oraz Pomorzan, podkreśla obraz-figurę czarno-złotej w kolorystyce stanicy (flagi) oraz fantastycznego lwio-orlego Gryfa. Ma to być ideowo-artystyczna alternatywa dla biało-czerwonej flagi polskiej i heraldycznego orła Rzeczpospolitej. Takie użycie nie ma znamion decyzji jedynie artystycznej, a raczej jest wyznacznikiem własności, odrębności i samowystarczal-

${ }^{24}$ J. Borzyszkowski, Wielkie Pomorze w poezji i pieśni Jana Trepczyka (1907-1989), w: Wielkie Pomorze. Mit i literatura, s. 153.

${ }^{25}$ Warto w tym miejscu przywołać jeszcze jeden z utworów J. Trepczyka zatytułowany znacząco: Më, a opublikowany w tomiku poetyckim Odecknienié (s. 25). Zawarta w nim idea Wielkiego Pomorza ukazana została przez przywołanie jeszcze innej grupy słowiańskiej: Obodrytów - zamieszkujących dawniej dzisiejszą Meklemburgię i Pomorze Przednie.

${ }^{26}$ J. Trepczyk, Marsz Naszyńców, w: tegoż, Lecë choranko. Pieśni kaszubskie. Wejherowo 1997, s. 56.

27 O Trepczyku-literacie i animatorze kaszubszczyzny pisał E. Kamiński, Jan Trepczyk - jeden ze zrzeszeńców. Próba oceny idei zrzeszeńskiej w twórczości literackiej. „Nasze Pomorze” 2008, nr 10, s. 167-181. 
ności w zakresie odwoływania się do znaków mitycznych, bez konieczności posiłkowania się tradycją polską, a tym bardziej niemiecką.

Jako ostatni z przykładów liryki Trepczyka należy przywołać tutaj pieśń Zemia rodnô, która w dzisiejszym środowisku kaszubskim ma dla jednych status głównego utworu śpiewanego podczas Dnia Jedności Kaszubów, dla drugich zaś stała się nieformalnym hymnem kaszubskim ${ }^{28}$. Usłyszymy tutaj znaczące dla motywu zaodrzańskiego słowa:

Zemia rodnô, pëszni kaszëbsczi kraju,

Òd Gduńska tu, jaż do Roztoczi bróm!

Të jes snôżô jak kwiat rozkwitłi w maju.

Ce, tatczëznã jô lubòtną tu móm. [...]

Tu jô dali mdã starżã zemi trzimôł

Skądka zôczątk rodnô naj rózga mô.

Tu mdã dali domòcëznë sã jimôł.

Jaż zajasni i nama brzôd swój dồ 29 .

Pieśń Trepczyka w pierwszej strofie ukazuje piękno Kaszub porównane do wiosennego kwiecia oraz terytorialną wielkość kaszubskiego dominium (od Gdańska do Rostocku). Ramy geograficzno-administracyjne Kaszub są tutaj umowne, istnieją na planie emocjonalno-mitycznym. Druga strofa (niezacytowana tutaj) przedstawia swoistą jedność polityczną średniowiecznych książąt Pomorza Gdańskiego - Sambora i Świętopełka. Wreszcie trzecia strofa wzywa do osobistej oraz społecznej odpowiedzialności za zachowanie tożsamościowych, wręcz narodowych wartości kaszubskich. Dostojna, patetyczna nieco melodia kompozycji muzycznej wraz z odświętną, patriotyczną wymową pieśni Trepczyka, sprawiają, że dla zespołowej i środowiskowej emocji utwór staje się szczególnie ważny.

Zaodrzańska przestrzeń stała się w liryku Trepczyka jednym z elementów procesu mitotwórczego. Po pierwsze zakłada on, że istniała w przeszłości jedność terytorialna, którą nazwać można Wielkim Pomorzem ${ }^{30}$. Po drugie, że istniała jednoznaczna doktryna polityczna, która prowadziła do stworzenia państwa kaszubskiego $w$ trzynastym wieku. Po trzecie wreszcie, że przebudzenie tożsamościowe Kaszubów w XX wieku z pewnością zaowocuje, jeśli nawet nie państwową samodzielnością, to przynajmniej kulturową wolnością ${ }^{31}$. W końcowym rezultacie hymn Trepczyka miał być zamanifestowaniem szczepowej godności, miał jedno-

\footnotetext{
${ }^{28}$ Szerzej pisałem o tym utworze w tekście: D. Kalinowski, Hymny pomorskie, w: Wielkie Pomorze. Tożsamość i wielokulturowość. Red. A. Kuik-Kalinowska, D. Kalinowski. Słupsk-Gdańsk 2011, s. 119-141.

29 J. Trepczyk, Odecknienié, Gdańsk 1966. Wersja z nutami: J. Trepczyk, Lecë choranko, s. 59.

${ }^{30}$ Szerzej o rozumieniu Wielkiego Pomorza przez autora pieśni pisze J. Borzyszkowski, Wielkie Pomorze w poezji i pieśni Jan Trepczyka (1907-1989), w: Wielkie Pomorze. Mit i literatura, s. 151-160.

31 O karierze pieśni Trepczyka pisze M. Pobidyńska w broszurce: „Zemia Rodnô” Jana Trepczyka. Analiza literacko-ideowa. Gdynia 2009, zwłaszcza s. 6-7.
} 
czyć różnorodność domowych ojczyzn kaszubskich w jedną od Gdańska do Rostocku ${ }^{32}$. Dawność interesów plemiennych Wenedów, polityka zewnętrzna i wewnętrzna księstwa Gdańskiego odpowiednio zinterpretowane stały się elementami działań agitacyjno-środowiskowych zrzeszeńców, które stwarzały wrażenie (choć takie nie były) silnego frontu ideowo-kulturowego.

W podobnym duchu pisał również Aleksander Labuda, drugi z ideologów omawianego tutaj ugrupowania, który w swej liryce stale wprowadzał historyczny kontekst ziemi pomorskiej ${ }^{33}$. Tego typu myślenie o świadomości kaszubskiej nie było może najszerzej reprezentowane $\mathrm{w}$ pierwszych dziesięcioleciach po II wojnie światowej, dlatego zrzeszeńcy nie uzyskali dużego wsparcia społecznego, jednakże dzisiaj czasami wyrastają na antenatów kaszubskiej tożsamości etnicznej.

I wreszcie na koniec warto wspomnieć o dramacie Wzénik Arkónë Jana Rompskiego, który powstał przed 1939 rokiem, jako jeszcze jedna artystyczna wizja zmityzowanych, heroicznych czynów Kaszubów ${ }^{34}$. Jest to najambitniejsza propozycja estetyczna środowiska zrzeszeńców, czyli czteroczęściowy dramat, pozytywnie oceniony przez autorytet spraw kaszubskich - Aleksandra Majkowskiego ${ }^{35}$. W czasie drugiej wojny światowej autor utracił rękopis sztuki, lecz częściowo ją zrekonstruował i od niedawna możemy się z nią zaznajomić36.

Dramat otwiera motto: „Dëchù, w krôj lecë Weletów / zarzekłëch bùdzëc òtroków...", które można rozumieć jako przewodnie zawołanie utworu. Głównym zadaniem tej sztuki miało być wzbudzanie uśpionej kaszubskości na Pomorzu. Rompski stawiał sobie za cel duchowe przewodnictwo, zarysowywał cele moralne

32 W Przedmóvie do pierwszego tomiku poetyckiego J. Trepczyka czytamy: „Z trójnech plemion, co zamieszkivelë Pomorze - wode Vjisłë v porënk jaż do Elbe ve vjeczór, a wode Njece v pôłnju jaż po naji modravi Bôłt, jeden leno dziso zawostôł zbjég, chtëren cëzenje nje wulég, a v dzélu przënômji utrzimôł jęzek, zvëk ë szlachotę Wojców. To Kaszëbji". Tegoż, Kaszebskij pjesnjôk. T. I. Rogoźno 1935, s. 3. W jeszcze innym zaginionym dziś poemacie historyczno-ludowym Trepczyka pt. Bjotkji morskjiego boga Zaodrze również było obecne jako dziedzina władztwa słowiańskiego.

${ }^{33}$ Inny ze zrzeszeńców - A. Labuda - również wywodzi pamięć o rodzimej mowie z dawnych przedchrześcijańskich czasów, co widoczne jest w liryku Z Weletów, w: Tegoż, Kaszëbsczim jesmë lëdã, Gdynia 1996, s. 29-30. Szerzej o tym w artykule: A. Kuik-Kalinowska, W świecie poezji Aleksandra Labudy. "Kaszëbsczim jesmë lëdã”. „Nasze Pomorze” 2008, nr 10, s. 153-159. Pozostaje jeszcze do interpretacji poemat Labudy Reknjica związany z historyczną bitwą pomiędzy związkiem wieleckim a margrabią Geronem, zwierzchnikiem sił saskich.

${ }^{34}$ W swej charakterystyce nawiązuję do ustaleń: D. Kalinowski, Dramaturgia Jana Romskiego, Tematy, idee, techniki, w: J. Rompski, Dramaty kaszubskie. Oprac. A. Kuik-Kalinowska, D. Kalinowski, J. Treder, Wejherowo-Gdańsk 2009, s. 5-44.

35 Jak informował A. Majkowski A. Bukowskiego w 1937 roku: „Piękne historyczne wiersze pisze Jan Rompski, młody człowiek, który się jako samouk przysposobił do matury." Cytat za: J. Borzyszkowski, Aleksander Majkowski (1876-1938), op. cit., s. 680.

36 Rekonstrukcja zakończyła się jedynie na napisaniu wspomnianego już wcześniej Przedestova i kilku scen drugiego aktu. O tragedii tej piszą również F. Neureiter, s. 189. 
i oceniał ówczesne zjawiska polityczne lub kulturowe. Główny bohater pierwszego aktu dramatu - Aliks - jest wybitną jednostką, człowiekiem biorącym na siebie zadanie wskrzeszenia uśpionych jak dotąd w duchowej beznadziei synów Weletów, czyli w głębszym sensie samych Kaszubów. Niemal pozbawione akcji akty dramatu rozgrywają się na wyspie Rugii i wokół jej najważniejszego miejsca, jakim dla Słowian jest Arkona. Aliks - człowiek spoza Rugii - ktoś o niezwykle intensywnym i bogatym życiu duchowym, trafia w obce sobie miejsce, które chce swoiście uzdrowić. Zapalony do działania główny bohater dramatu nie znajduje jednak $\mathrm{w}$ sobie dość mocy, aby z powodzeniem wypełnić misję budzenia upadłych na duchu Pomorzan. Przechodzi jednak swoistą edukację ideową dzięki różnego typu duchom i ich przewodnikowi - Guślarzowi. Od duchów dowiaduje się, na czym polega świętość kaszubskiej mowy i jakie są najlepsze sposoby okazania czci dla Pomorza-Macierzy. Uświadomiony w ten sposób Aliks rozpoczyna walkę o bardziej pragmatyczne cele. Fragment drugiego aktu ukazuje, że ma on być duchowym wspomożycielem dla Franca Kosowa, który swymi czynami i żarliwością pociągnie ku politycznym celom większe rzesze ludu kaszubskiego. Okazuje się bowiem, że społeczność welecka (kaszubska) podzielona jest na grupę wierną obyczajom słowiańskim (uosabia ją Bronisa) oraz grupę zgermanizowaną (reprezentowaną przez Horsta).

Śmierć Bronisy i związana z nią obrzędowość pustej nocy opisane w drugim akcie przynoszą ze sobą spolaryzowanie stanowisk wobec rodzimej tradycji. Większość bohaterów będzie się skłaniała ku słowiańskiemu wyborowi tożsamościowemu, jednakże mniejszość (lecz za to taka, która ma większą władzę decyzyjną) zgłosi raczej akces do żywiołu germańskiego. Arkona w dramacie Rompskiego staje się punktem, w którym dokonuje się przesilenie losów Zachodniej Słowiańszczyzny, z jednej strony nadchodzą Germanie, kończąc erę przedchrześcijańską, z drugiej jednak pojawiają się $\mathrm{w}$ dalekiej perspektywie nowe czasy z odżywionymi ruchami narodowymi, dzięki którym Słowianie, a wśród nich Kaszubi, mogą powrócić na pomorskie Zaodrze. Jak czytamy w dramacie:

Gwës kòżdi mô czas swój, do czej mù żëc.

Jeden, jak całé nôrodë!

Le grädszé nôrodu kònanié,

Jiż w mãce dëszë ùchôdanié.

Dosc wezdrzec tu w Zôpadnëch Słowianów!

Dzeż tu sã mają zatacëc?

Na pòjidze cëzëch są bùwronów.

Négą je Słowińc - jak tu żëc?!

Zôpadné słuńce wschôdô kr'wawé,

Wzéniczné switkô bladé, bladé... ${ }^{37}$

${ }^{37}$ J. Rompski, Wzénik Arkónë, w: tegoż, Dramaty kaszubskie, s. 214-215. 
Kulturowo-ideowy kontekst sztuki Rompskiego w kilku miejscach wiąże się z ideami Młodokaszubów, co przynosi ze sobą sytuację dialogu pokoleniowego ${ }^{38}$. Aliksa można w takim układzie odbierać jako refleks postaci Remusa z powieści Aleksandra Majkowskiego; tyle, że nie chodziłoby tutaj o podobieństwa losów czy dyspozycji psychologicznych bohaterów, ale o współbieżną postawę krzewienia i budzenia tożsamości kaszubskiej. Jeszcze bardziej zasadnym wzorcem literackim ze świata literatury Młodokaszubów byłaby dramaturgia Jana Karnowskiego, a zwłaszcza jego sztuka Otrôk Swantewita. W obydwu sztukach napotykamy nadnaturalne i realne istoty działające również w rejonie Zaodrza, w obydwu mamy do czynienia z podobnym bohaterem realizującym zadanie budzenia Kaszubów z marazmu. Propozycję dramaturgiczną Rompskiego można zatem interpretować jako artystyczne dialogowanie z wcześniejszym utworem Karnowskiego.

Rompski ma jednakże ambicję stworzenia własnej wersji pradziejów Kaszubów, pragnie możliwie bogato i atrakcyjnie artystycznie przedstawić nie tylko koncepcję dotyczącą przyczyn utraty zaodrzańskiej ojczyzny, ale i opisać świat wyobraźni, wrażliwości i myśli konkretnych ludzi dawnych czasów. Zasługą dramatu Rompskiego jest, z jednej strony, charakterystyka prakaszubskiej kultury, która przeszła w germańskie ręce z powodu własnej nieudolności politycznej oraz, z drugiej strony, opis przywar i ograniczeń naiwnych Kaszubów, a także konsekwencje podstępów ich wrogów.

\section{KASZUBSKO-SŁOWIAŃSKA PAMIĘĆ}

W krótkim podsumowaniu wszystkich przywołanych utworów literatury kaszubskiej można zauważyć, że eksploatują one treści historyczne, które bardziej wynikały z literackiego przetwarzania zapisków dawnych kronikarzy, aniżeli z historycznej wiedzy opisywanej przez nich literatów rzeczywistości Zaodrza. W ujęciach literackich Kaszub znaczącą rolę odegrały koncepcje „dziejów bajecznych", które miały przede wszystkim funkcje terapeutyczną 39 . Rozpamiętywanie bitwy pod Reknicą, losów Słowian połabskich czy znaczenia Arkony miało w sensie życia duchowego społeczności kaszubskiej działać dydaktycznie i otrzeźwiająco. Dydaktycznie - ponieważ dawało wiedzę o ziemi ojców, otrzeźwiająco - ponieważ zachęcało do świadomościowego przebudzenia. Akcentowanie prakaszubskości Zaodrza w sytuacji zagrożenia germanizacją stawiało aktualne niedogodności i zagrożenia $\mathrm{w}$ szerokiej historiozoficznej perspektywie, która przynosiła

${ }^{38}$ O związkach ideowych J. Rompskiego z Młodokaszubami pisali: J. Drzeżdżon, Piętno Smętka. Z problemów kaszubskiej literatury regionalnej lat 1920-1939, Gdańsk 1973, s. 111; J. Zbrzyca, Na tropach cierpiętnictwa, „Litery” 1970, nr 12.

39 Specyfikę tej problematyki w stosunku do tradycji polskiej wieloaspektowo omawiał: J. Maślanka, Literatura a dzieje bajeczne. Warszawa 1984. 
pewną nadzieję dla słowiańskiego odrodzenia narodowego. Choć dzieje bajeczne były $\mathrm{w}$ dziewiętnastym i dwudziestym wieku stale weryfikowane przez naukowe badania historyczne, $\mathrm{w}$ literaturze ciągle panowały odmienne sposoby przedstawiania świata, stąd kaszubscy literaci tworzyli własne mity i mitologie, które pozwalały im snuć swoją własną wersję twórczości „,ku pokrzepieniu serc”.

Kilka obrazów Zaodrza, które przywołałem w wybranych utworach literatury kaszubskiej, koresponduje z mitem bogatej, sławnej, pełnej mocy Winety, umiejscowianej na wyspie Wolin ${ }^{40}$. Wineta była wielkością utraconą, chwałą, która zaginęła, pozostając w pamięci dzięki ludowym podaniom i literackim ujęciom. Dla literatury kaszubskiej Arkona była jednak bardziej namacalna, wciąż możliwa do odwiedzenia i zobaczenia materialnych pozostałości po kulturze ojców. Wineta zaś istniała głównie $\mathrm{w}$ przestrzeni wyobraźni. Współczesność nie zniszczyła całkowicie duchowej wyniosłości Arkony, nie zatarła wszystkich śladów historii i wypływających z niej symbolicznych konotacji, Winetę zaś można było doświadczyć jedynie w słuchaniu ludowych opowieści, czytaniu pomorskich legend lub, wreszcie, w wysiłku dopatrywania się w podwodnych skałach płycizn Wolina ruin dawnego grodu. Być może to dla Kaszubów było zbyt mało, może też zbyt sugestywnie pisali o tym autorzy polscy ${ }^{41}$.

Spojrzenie na Zaodrze z perspektywy literatury kaszubskiej wynika ze zinterpretowania treści historycznych, lecz kieruje się jednocześnie ku czasami mitycznym opowieściom o bogactwie materialnym i duchowym słowiańszczyzny. Literackie przedstawienie przestrzeni kulturowej Rugii czy Połabia ma za zadanie ukazać słowiańską moc istniejącą w Europie jeszcze przed dominacją chrześcijaństwa, ma również ideowo wspomóc walczące o swoje domowe i państwowe ojczyzny ludy słowiańskie ${ }^{42}$. Zaodrze dla Kaszubów więc to jednocześnie chlubna i ciemna przeszłość Słowiańszczyzny, wciąż na nowo odciskająca się na współczesności.

${ }^{40}$ Najszerzej pisze o tym R. Kiersnowski, Legenda Winety. Kraków 1950. O Winecie wspomina również J. Samp, Mitopeje pobrzeża Bałtyku. Gdańsk 2009, s. 129-134.

${ }^{41}$ Myślę tutaj głównie o T. i jego Końcu Wenety lub Mścicielu Wenety (1910-1913). Zob. szerzej o tej problematyce T. Linkner, Z mare tenebrarum na stoneczny Hel. W kręgu myśli battycko-pomorskiej Tadeusza Micińskiego. Gdańsk 1987.

42 J. Kłoczowski, Młodsza Europa. Europa Środkowo-Wschodnia w kręgu cywilizacji chrześcijańskiej średniowiecza. Warszawa 2003; Z. Skrok, Stowiańska moc czyli o niezwykłym wkroczeniu naszych przodków na europejska arenę. Warszawa 2006. 